\title{
Planting Density and Time of White Lupine Relay Intercropping in TEFF (Eragrostis tef (Zucc.) Trotter) in Burie District, North Western Ethiopia
}

\author{
Tesfaw Fetene \\ College of Agriculture and Natural Resource, Debre Markos University, Ethiopia \\ Getachew Alemayehu $(\mathrm{PhD})$ \\ College of Agriculture and Environmental Sciences, Bahir Dar University, Ethiopia \\ Zewudie G/Tsadik (PhD) \\ ATA, Ext, \& Commodity Team STE, Tef \&Rice Value Chain, Addis Ababa, Ethiopia
}

\begin{abstract}
The experiment was conducted during 2015/16 main rainy season in Burie District, North Western Ethiopia with an objective of evaluating the potential of lupine relay intercropping with different density and rely time of lupine in teff. Factorial combinations of 3 relay intercropping time(after 4,6,and 8 weeks of teff sowing), 2 interrow spacing $(40 \mathrm{~cm}$ and $60 \mathrm{~cm})$ and 2 intra-row spacing of lupine $(20 \mathrm{~cm}$ and $30 \mathrm{~cm})$, totally 12 treatment combinations, and 2 sole cropping of teff and lupine were laid out in randomized complete block design at three replications. The collected was subjected to ANOVA using SAS (9.2) software. LER and MAI were calculated to evaluate the yield advantage of lupine relay intercropping for which the highest LER (1.62) and MAI (20402.42 birr/ha) was obtained from early intercropping accompanied with narrower intra and inter row spacing of lupine.
\end{abstract}

Keywords: rely intercropping, LER, M AI

DOI: $10.7176 / \mathrm{JBAH} / 11-19-01$

Publication date:October $31^{\text {st }} 2021$

\section{INTRODUCTION}

White Lupine belongs to genes and species Lupinus albus L. and family Leguminosae (also called Fabaceae), the third largest family (EFSA, 2005). It is a cool-season legume crop. Lupins are adapted to well drained, light to medium textured soil and it is sensitive to soil $\mathrm{P}^{\mathrm{H}}$ preferring acid to near-neutral conditions ( $\mathrm{pH}$ of 4.5 to 7.5) (Jansen, 2006; Likawent Yeheyis et al., 2010).

There are many plant species with significant feed, food, soil fertility maintenance (Likawent Yeheyis et al., 2010) and industrial potential which remain underutilized. The vast numbers of those underutilized species represent an enormous untouched commodity resource which can help to meet the increasing demand for food and nutrition, energy, medicines and industrial needs (Bhat and Karim, 2009). Among those underutilized crops in Ethiopia, according to Likawent Yeheyis (2012), lupine is the most important traditional crop mostly produced and consumed by smallholder farmers in the North-Western part of the country.

The farmers in north-western part of the country grow white lupine as a border crop for the protection of cereal crops. It is traditionally gown as intercrop with cereals and oil crops by low input farmers and is restricted to low-income classes, to times of drought (Jansen, 2006).

In the district the farmers traditionally use white lupine as a border crop with pepper, millet and teff where the productivity of white lupine is very low and is given very less management practices. However, besides its use for soil fertility improvement, the price of lupine is increasing from time to time. There for this research was initiated to evaluate the potential of white lupine relay intercropping in teff; to determine the influence of time of relay intercropping and planting density on the productivity of lupine and to assess the economic benefits of lupine relay intercropping in teff in the study area.

\section{MATERIAL AND METHODS}

\subsection{Description of the Study Area}

On farm experiment was conducted at Wangedam rural village in Burie District, North Western Ethiopia. The experimental site is found at $153 \mathrm{~km}$ far from Bahir Dar and $411 \mathrm{~km}$ from Addis Ababa and located at $10^{\circ} 44^{\prime}$ Nlatitude and $37^{\circ} 06^{\prime} \mathrm{E}$ longitude with an elevation of 2091 meters above sea level. Average minimum and maximum temperatures of the area are $12^{\circ} \mathrm{C}$ and $28.4^{\circ} \mathrm{C}$, respectively. The average total annual rainfall of the site is about $945 \mathrm{~mm}$.

The soil of the experimental site was well drained red-brown nitosol. Composite soil sample was prepared from the mixture of samples collected on the top $20 \mathrm{~cm}$ by using a sampling spoon along "'W" shape of the 
experimental plot. The composite soil sample was analyzed for its texture, $\mathrm{pH}$, organic matter (OC), total nitrogen content (TN), available phosphorous (Av.P) and cation exchange capacity (CEC) using their respective standard methods and procedures. The results are presented below in (Table 2.1).

Table 2.1. Physical and chemical properties of the surface soils $(0-20 \mathrm{~cm})$ of the study site

\begin{tabular}{|c|c|c|c|c|c|c|c|c|}
\hline pH & OC & TN & Av.P & CEC & \multicolumn{4}{|c|}{ Texture } \\
\hline $\begin{array}{c}\left(\mathrm{H}_{2} \mathrm{O}\right) \\
1: 2.5\end{array}$ & $(\%)$ & $(\%)$ & $(\mathbf{p p m})$ & $\left(\mathrm{cmol}^{+} \mathrm{kg}^{-1}\right)$ & $\%$ clay & $\%$ silt & \%sand & Texture class \\
\hline 4.88 & 1.33 & 0.11 & 18.8 & 28.9 & 60 & 24 & 16 & Clay \\
\hline
\end{tabular}

\subsection{Planting Materials used for the Experiment}

The research was conducted by using "Quncho" teff variety obtained from Ethiopian seed enterprise, Bahir Dar branch and local white lupine bought from the farmers.

\subsection{Experimental Treatments, Design and Procedures}

Factorial combinations of three times of relay intercropping (4, 6 and 8 weeks after teff sowing), two inter-row spacing $(40 \mathrm{~cm}$ and $60 \mathrm{~cm})$ and two intra-row spacing $(20 \mathrm{~cm}$ and $30 \mathrm{~cm})$ of lupine in teff field as well as two sole cropping of teff and lupine for comparison purposes, totally 14 treatments, were laid out in randomized complete block design with three replications.

A plot of land $725 \mathrm{~m}^{2}(62.5 \mathrm{mx} 11.6 \mathrm{~m})$ was prepared according to farmers practice in the area (oxen-plough) four times. The gross sizes of experimental plots were $4 \mathrm{mx} 3.2 \mathrm{~m}\left(12.8 \mathrm{~m}^{2}\right)$ but the net plot size was different for different treatments. Thus the net plot size was $3.4 \mathrm{mx} 2.8 \mathrm{~m}\left(9.52 \mathrm{~m}^{2}\right)$ for teff and $3.4 \mathrm{mx} 2.4 \mathrm{~m}\left(8.16 \mathrm{~m}^{2}\right)$ for sole, T1, T2. T5 and T6 lupine whereas for T3, T4, T7 and T8 of lupine was $3.4 \mathrm{mx} 1.8 \mathrm{~m}\left(6.12 \mathrm{~m}^{2}\right)$. The replications and the plots were separated one from another with $1 \mathrm{~m}$ and $0.5 \mathrm{~m}$ respectively.

In the mid of July, teff seed was drilled at the rate of $5 \mathrm{~kg} / \mathrm{ha}$ in rows at the spacing of $20 \mathrm{~cm}$. Sole cropping of lupine was sown on the same date of teff sowing at inter- and intra-row spacing of $40 \mathrm{~cm} x 20 \mathrm{~cm}$, respectively. DAP and Urea fertilizers were applied at the rates of $100 \mathrm{~kg}$ and $50 \mathrm{~kg}$ per hectare, respectively, as used by the community. The whole DAP was applied at the time of sowing, while Urea was applied in split two times with equal proportion soon after the first and the second weeding after 20 and 42 days of teff sowing, respectively. The remaining agronomic practices were done timely as per their respective recommendations used for teff in the area.

Table2.2. Treatment combinations used for the study

\begin{tabular}{|c|c|c|c|}
\hline \multicolumn{2}{|c|}{ Lupine plant density } & $\begin{array}{l}\text { Time of lupine relay } \\
\text { intercropping after teff sowing }\end{array}$ & Treatment combinations \\
\hline Intra row spacing & Inter row spacing & \multirow{4}{*}{$\begin{array}{l}\text { 4weeks(T4) } \\
\text { 6weeks(T6) } \\
\text { 8weeks(T8) }\end{array}$} & T4I2R2(T1) \\
\hline $40 \mathrm{~cm}(\mathrm{R} 2)$ & $20(\mathrm{I} 2)$ & & T4I3R2(T2) \\
\hline \multirow[t]{2}{*}{$60 \mathrm{~cm}(\mathrm{R} 3)$} & $30(\mathrm{I} 3)$ & & T4I2R3(T3) \\
\hline & & & T4I3R3(T4) \\
\hline & & & T6I2R2(T5) \\
\hline & & & T6I3R2(T6) \\
\hline & & & T6I2R3(T7) \\
\hline & & & T6I3R3(T8) \\
\hline & & & T8I2R2(T9) \\
\hline & & & T8I3R2(T10) \\
\hline & & & T8I2R3(T11) \\
\hline & & & T8I3R3(T12) \\
\hline & & & Sole teff (13) \\
\hline & & & Sole lupine (14) \\
\hline
\end{tabular}

\subsection{Data Collection}

2.4.1 Vegetative growth of lupine:

Plant height; average height of 5 randomly selected plants at physiological maturity in the net plot area in centimeter measured with linear meter from the base of the main stem to the tip of the plant

Stand count; number of total plants in the net plot area of each treatment at physiological maturity and converted into hectare basis

Number of primary and secondary branches per plant; the average number of primary and secondary branches per plant of the 5 randomly selected plants in the net plot area of each treatment at physiological maturity

2.4.2 Grain yield and related parameters of lupine

Number of pods per plant: average number of pods per plant of five randomly selected plants in the net plot 
area of each treatment

Number of seeds per pod: average number of seeds per pod of five randomly selected plants in the net plot area of each treatment. It was summed and divided to the number of pods

100 seeds weight (gm.): after harvesting of lupine in the net plot area of each treatment, it was sun dried properly, threshed and cleaned to separate grains from debris. Then, hundred seeds were randomly taken from each plot and weighed to determine 100 seeds weight in gm.

Biomass yield (kg/ha): after harvesting lupine in the net plot area of each treatment at 90\% physiological maturity, it was sun dried properly and weighed with sensitive balance and converted into hectare basis

Grain yield (kg/ha): after harvesting, drying, threshing and cleaning of lupine per the net plot area of each treatment, lupine grains were weighed and then converted into hectare basis.

Harvesting index (\%): it is the percentage of lupine grain yield to biomass yield ratio of each treatment plot

\subsection{Determination of Productivity Indices and Monetary Advantage Index}

Land equivalent ratio was used as productivity index to compare the yield advantages of intercropping system over sole cropping. Besides, the monetary advantage index was also used to compare the intercropping monetary value with sole cropping.

\subsubsection{Land equivalent ratio (LER)}

LER indicates the efficiency of intercropping for using the resources of the environment compared with mono cropping. The value of unity is the critical value. When the LER is greater than one, the intercropping favors the growth and yield of the species. In contrast, when LER is lower than one the intercropping negatively affects the growth and yield of the plants grown in mixtures. The LER was calculated as (Willey, 1972).

$L E R=(L E R$ Lupine $+L E R$ tef $) ; L E R$ Lupine $=Y L I / Y L$ and $L E R$ tef $Y T I / Y T$

Where, $Y L$ and $Y \mathrm{~T}$ are the yields of lupine and teff, respectively, as sole crops and $Y L I$ and $Y$ TI are the yields of lupine and teff, respectively, as intercrops.

\subsubsection{Monetary advantage index (MAI)}

The monetary advantage was determined by the existing local market prices of both crops. Due to the fluctuation of the market price, the value of combined intercrops in each cropping system was by prevailing market price of each component crop at the time of experiment (ETB/kg). The monetary advantage index (MAI) was calculated by the formula developed by Willey (1979):

$M A I=\quad$ (Value of Combined Intercrops) $(L E R-1)$

$$
L E R
$$

The value of combined inter crops $=($ yield of teff $\mathrm{x}$ price of teff $)+($ yield of lupine $\mathrm{x}$ price of lupine $)$

\subsection{Data Analysis}

All collected data were subjected to analysis of variance using SAS (version 9.2) and mean separation of significant treatments were carried out using the least significant difference (LSD) test.

\section{RESULTS AND DISCUSSION}

3.1 Effect of Planting Density and Time of Lupine Relay Intercropping in Teff on the Vegetative Growth of lupine

Plant height

The height of lupine plant was highly significantly $(\mathrm{P}<0.01)$ affected by main effect of relay time and significantly $(\mathrm{p}<0.05)$ by the interaction effects of relay time with teff lupine ratio, relay time with intra row spacing. It was also significantly $(\mathrm{p}<0.05)$ affected by the interaction of the three factors (Table 3.1).The tallest plant height of white lupine was recorded from the sole lupine $(1.23 \mathrm{~m})$ followed by $(0.93 \mathrm{~m})$ early sown white lupine with narrower intra row and inter row (T4xR2xI2) spacing and shortest $(0.60 \mathrm{~m})$ from the late sown lupine with wider inter and intra row spacing (T6xR3xI3) (Table 3.1). The reason might be due to the fact that teff crop caused nearly greater dominance upon growth resources over lupine in the early stage of the minor crop. The other possible reason could be shading and lodging effect of teff over lupine. This is in agreement with Tamiru Hirpa (2013) who stated that later introduction of legume crops in maize gave a better establishment of maize ahead of the later introduced intercrop, thereby suppressing growth and lowers down the canopy of legume.

\section{Number of primary and secondary branches per Plant}

The analysis of variance revealed that number of primary and secondary branches plant ${ }^{-1}$ of lupine crop intercropped with teff was highly significantly $(\mathrm{P}<0.01)$ affected by the main effects of relay intercropping time. The number of primary and secondary branches were also significantly $(p<0.05)$ affected by the interaction effect of intra row spacing with relay intercropping time, teff lupine ratio with relay intercropping time and by the interaction of the three factors (Table 3.1).

The lupine plants sown earlier (after 4 weeks) with narrower inter $(40 \mathrm{~cm})$ and intra row $(20 \mathrm{~cm}) \mathrm{spacing}$ produced more number of primary branches (2.40) next to sole crop (5.6) whereas less number of primary 
branches (1.13) was recorded when sown later (after 6 weeks) with wider inter $(60 \mathrm{~cm})$ and intra row $(30 \mathrm{~cm})$ spacing which indicated that teff crop created greater competition for growth resources on white lupine growth parameters. Greater decline on the number of secondary branches was also recorded with the interaction of delayed intercropping time and plating density of lupine in teff. The highest

number of secondary branches were recorded from the sole crop (2.73) followed by early sown and narrower inter row and intra row spacing (1.80) (Table 3.1). The result was in line with the work of Tamiru Hirpa (2013) who reported that trends of drastic decline in number of branches in legumes was observed with delay in intercropping and the overall poorest growth was recorded when they were introduced 8 weeks after maize sowing. In addition, Adipala et al. (2002) reported that cowpea simultaneously planted with maize had on average more branches per plant than those planted two and four weeks after planting of maize.

Stand count

It was significantly $(\mathrm{p}<0.05)$ affected by the interaction effects of the three factors for which the highest stand was recorded from the sole crop and the lowest from the delayed sown lupine crop by 6weeks with wider intra $(30 \mathrm{~cm})$ and inter $(60 \mathrm{~cm})$ spacing (table 3.1$)$

Table 3.1. Three way interaction effects of intra row spacing, teff lupine ratio and relay intercropping time on the vegetative growth of lupine in 2015/16 in Burie District

\begin{tabular}{|c|c|c|c|c|c|c|}
\hline \multicolumn{4}{|c|}{ T $\times$ R x I } & \multicolumn{3}{|c|}{ upine } \\
\hline $\mathbf{T}$ & $\mathbf{R}$ & I & PH & $\mathbf{1}^{0} \mathrm{~B}$ & $\mathbf{2}^{0} \mathrm{~B}$ & SC \\
\hline \multirow[t]{4}{*}{ T4 } & $\mathbf{R 2}$ & I2 & $0.93 b$ & $2.40 \mathrm{~b}$ & $1.80 \mathrm{~b}$ & $108072.9 a$ \\
\hline & & I3 & $0.90 \mathrm{~b}$ & $2.27 \mathrm{~b}$ & $1.73 b c$ & $63020.83 b$ \\
\hline & $\mathbf{R 3}$ & I2 & $0.92 b$ & $2.27 \mathrm{~b}$ & $1.87 \mathrm{~b}$ & $62239.58 b$ \\
\hline & & I3 & $0.92 b$ & $2.27 \mathrm{~b}$ & $1.80 \mathrm{~b}$ & $39583.33 d$ \\
\hline \multirow[t]{5}{*}{ T6 } & $\mathbf{R 2}$ & I2 & $0.63 c$ & $1.27 \mathrm{c}$ & $1.06 \mathrm{bc}$ & $53125.00 \mathrm{c}$ \\
\hline & & I3 & $0.62 \mathrm{c}$ & $1.20 \mathrm{c}$ & $1.06 \mathrm{bc}$ & $31250.00 \mathrm{e}$ \\
\hline & R3 & I2 & $0.60 \mathrm{c}$ & $1.20 \mathrm{c}$ & $1.00 \mathrm{c}$ & $30468.75 \mathrm{e}$ \\
\hline & & I3 & $0.60 \mathrm{c}$ & $1.13 \mathrm{c}$ & $1.00 \mathrm{c}$ & $22656.25 f$ \\
\hline & Sol & & $1.23 \mathrm{a}$ & $5.60 \mathrm{a}$ & $2.73 a$ & $120312.5 \mathrm{a}$ \\
\hline \multicolumn{3}{|c|}{ Sig. difference } & $*$ & $*$ & $*$ & $*$ \\
\hline \multicolumn{3}{|c|}{$\mathbf{S E} \pm$} & 0.03 & 0.11 & 0.40 & 686.66 \\
\hline \multicolumn{3}{|c|}{ CV (\%) } & 1.5 & 1.1 & 19.3 & 5.5 \\
\hline
\end{tabular}

* Significant at $5 \%, \mathrm{PH}=$ Plant height; $1{ }^{0} \mathrm{~B}=$ Number of primary branch; $2^{0} \mathrm{~B}=$ Number of secondary branch; $\mathrm{SC}=$ stand count; $\mathrm{CV}=$ Coefficient of variation; $\mathrm{I}, \mathrm{R}$ and $\mathrm{T}$ are intra row spacing, teff lupine ratio and relay time respectively; means followed with different letters are significant at 0.05 level of error

\subsection{Grain Yield and Related Traits of Lupine as Influenced by Planting Density and Time of Lupine Relay Intercropping in Teff Number of pods and seeds}

The analysis of variance revealed that number of pods plant ${ }^{-1}$ and number of seed pod ${ }^{-1}$ of white lupine were highly significantly $(\mathrm{P} \leq 0.01)$ affected by the main effect of relay intercropping time. In addition to this number of pods per plant and seed number per pod was also significantly $(\mathrm{p}<0.05)$ affected by the interaction effect of relay intercropping time with intra row spacing and relay inter cropping time with teff lupine ratio and by the interaction effects of the three factors (Table 3.2).

The highest pod per plant (33.47) was recorded from sole crop followed (25.93) by earlier sowing (after 4 weeks) and narrower inter and intra row spacing of lupine. Regardless of the teff lupine ratio and the spacing used, number of pods per plant showed a decreasing trend as time of sowing was extended (Table 3.2). In line with this finding, Muoneke et al. (2007) reported that delayed interceding reduced number of soybean pods per plant. Similarly Tamiru Hirpa (2013) also showed that a consistent reduction in number of pods per plant was recorded with delay in interceding of the legume crops, in which soybean produced highest numbers throughout the cropping system treatments.

The highest number of seed per pod (4.67) was recorded from the sole crop whereas the least number of seeds per pod (2.27) was recorded from the delayed (6 weeks) of teff sowing. This could be because of the suppression effect of the already established teff crop on the lately sown lupine. On the other hand the main effects of planting density of white lupine did not significantly $(p>0.05)$ affect the pod number and seed per pod of the crop.

Biomass yield

The above ground biomass weight was highly significantly $(\mathrm{P} \leq 0.01)$ affected by the main effect, the interaction of relay time with intra row spacing and relay time with inter row spacing. The biomass yield of lupine was also significantly $(p<0.05)$ affected by the interaction effects of inter row spacing with intra row spacing and the 
interaction effects of the three factors. The greatest amount of biomass yield $(8263.30 \mathrm{~kg} / \mathrm{ha})$ was recorded from the early (after 4 weeks) and narrower inter row $(40 \mathrm{~cm})$ and intra row $(20 \mathrm{~cm})$ than the remaining relay intercropping time and planting density of lupine in teff (Table 3.2). This result was corroborated with Bismillah and Khaliq (2004), who reported that sole cropped soybean showed higher biological and seed yield as compared to soybean-cotton based intercropping systems. Similarly Maluleke et al. (2004) accounted consistently reduced biomass accumulation of late-planted lablab in the intercropping system with maize compared to those simultaneously planted. In addition in agreement with Yayeh Bitew et al. (2014) also stated that the highest lupine seeding ratio intercropped with full cereal seed rate gave the highest biomass yield.

\section{Grain yield}

The grain yield of white lupine was highly significantly $(\mathrm{P} \leq 0.01)$ affected by the main effect, the interaction of relay time with intra row spacing and relay time with inter row spacing. The grain yield of lupine was also significantly $(\mathrm{p}<0.05)$ affected by the interaction effects of inter row spacing with intra row spacing and the interaction effects of the three factors. The highest yield $(2573.53 \mathrm{~kg} / \mathrm{ha})$ of lupine was obtained from the sole crop while the smallest $(163.40 \mathrm{~kg} / \mathrm{ha})$ was from the delayed sowing with wider intra and inter row spacing (Table 3.2). This was in agreement with the work of Confaloneet al. (2010) who reported that the time of introducing cowpea into maize significantly affected the yield of cowpea; simultaneous planting showed increasing cowpea yield when compared to introducing cowpea into maize when delayed by two or four weeks. Similarly Abdul-Rahaman (2010) showed that the highest grain yield by $1619.51 \mathrm{~g} / \mathrm{m} 2$ belonged to the first planting date and the lowest grain yield by $888.43 \mathrm{~g} / \mathrm{m} 2$ belonged to the third planting date where in the first planting date the soybean growth stages were more adapted with environmental conditions. The yield loses might be due to inter specific competition between teff and white lupine bean for below and above ground growth factors i.e. soil moisture, nutrient, space and solar radiation. Besides the competition, mainly during the vegetative growth stage and associated vigorous growth may cause shading of the lupine and thereby reduce its growth during later growth stages resulting in low yielding ability.

\section{Harvest index and hundred grain weight}

Harvesting index and hundred grain weight was highly significantly $(\mathrm{P} \leq 0.01)$ affected by the main effects of relay inter cropping time whereas except harvesting index which was significantly $(p<0.05)$ affected by the main effects of the teff lupine ratio, the harvesting index and the hundred seed weight was not significantly $(p>0.05)$ affected by the main effects of planting densities of lupine in teff. On the other hand with the exception of hundred seed weight which was not significantly $(p>0.05)$ affected by the interaction effects of intra and inter row spacing of lupine, harvesting index and hundred seed weight were significantly $(p<0.05)$ affected by the tow way and three way interaction effects of relay intercropping time with different planting densities of lupine in teff. The highest harvesting index (28) was obtained from the sole crop than all treatments sown after the establishment of teff with different planting densities (Table 3.2).This might be due to the higher competition and shading effect of teff crop over the delayed lupine crop. Similarly the highest hundred seed weight was recorded from the sole crop followed by the earlier sowing of lupine with narrow inter and intra row spacing and the lowest being from the lately sown lupine plant with wider inter and intra row spacing (Table 3.2). This was in corroboration with Carruthers et al. (2000), who stated that 100 seeds weight of soybean decreased by intercropping and for delayed intercropping three weeks after maize emergence.

Table 3.2. Three way interaction effects of planting density and time of lupine relay intercropping in teff on yield related traits of lupine in 2015/16 in Bure District

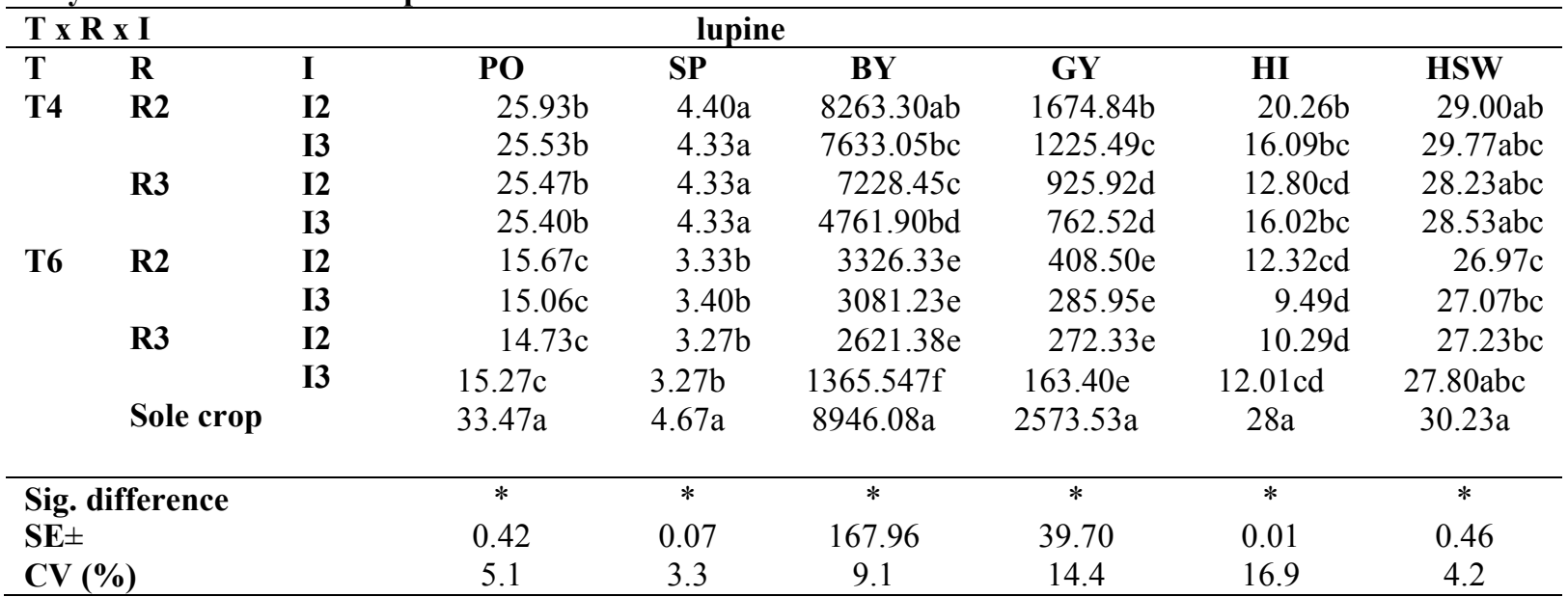

* Significant at 5\%; PO= Number of pod per plant; $\mathrm{SP}=$ Number of seed per pod; $\mathrm{BY}=$ biomass yield $\left(\mathrm{kgha}^{1}\right)$; $\mathrm{GY}=$ Grain yield (kgha-1); HSW= Hundred seed weight $(\mathrm{g})$; $\mathrm{HI}=$ Harvest index $(\%)$; $\mathrm{CV}=$ Coefficient of variation; I, R and $\mathrm{T}$ are intra row spacing, teff lupine ratio and relay time respectively; means followed with 
different letters are significant at 0.05 level of error

\subsection{Productivity of Intercropping}

\subsubsection{Land equivalent ratio}

The LER value was significantly $(p<0.05)$ affected by the interaction effects of relay time, inter row and intra row spacing of lupine in teff. The highest LER (1.62) was recorded from relay inter cropping of lupine at four weeks after teff sowing with $20 \mathrm{~cm}$ intra row spacing and $40 \mathrm{~cm}$ inter row spacing (Table 3.3). This showed that relay intercropping of lupine in teff after four weeks with narrower plant spacing provided $62 \%$ yield advantage than the sole cropping. The total LER except after eight weeks of teff sowing was more than a unity showing that intercropping of lupine with teff was advantageous in all instances rather than sole cropping. Similarly Sharma et al. (2000) and Thippeswamy and Alagundagi (2001) reported that higher yields and LER values in sweet sorghum-soybean pattern with simultaneous seeding.

\subsubsection{Monetary advantage index}

MAI value was significantly $(\mathrm{p}<0.05)$ affected by the interaction effects of relay intercropping time with inter row spacing, inter row spacing with intra row spacing and by the three way interaction effects of the three factors. The highest MAI (20402.42 Birr/ha) and the lowest (2111.42 Birr/ha) was obtained from the early sowing of lupine with narrow intra and inter row spacing and with delayed sowing of lupine with wider intra and inter row spacing respectively (Table 3.3). This could be due to the higher yield and LER obtained from the intercropping of these two crops. A survey conducted in Kenya by Odendo and Kalybara (2004) also showed that changing from sole maize cropping to maize-bean intercropping resulted in a MRR of 370\%, in which they concluded that growing maize in association with beans is overwhelmingly advantageous compared with planting maize as a sole crop.

Table3.3. Three way interaction effects of intra row spacing, teff lupine ratio and relay intercropping time on the LER and MAI in Burie District in 2015/16

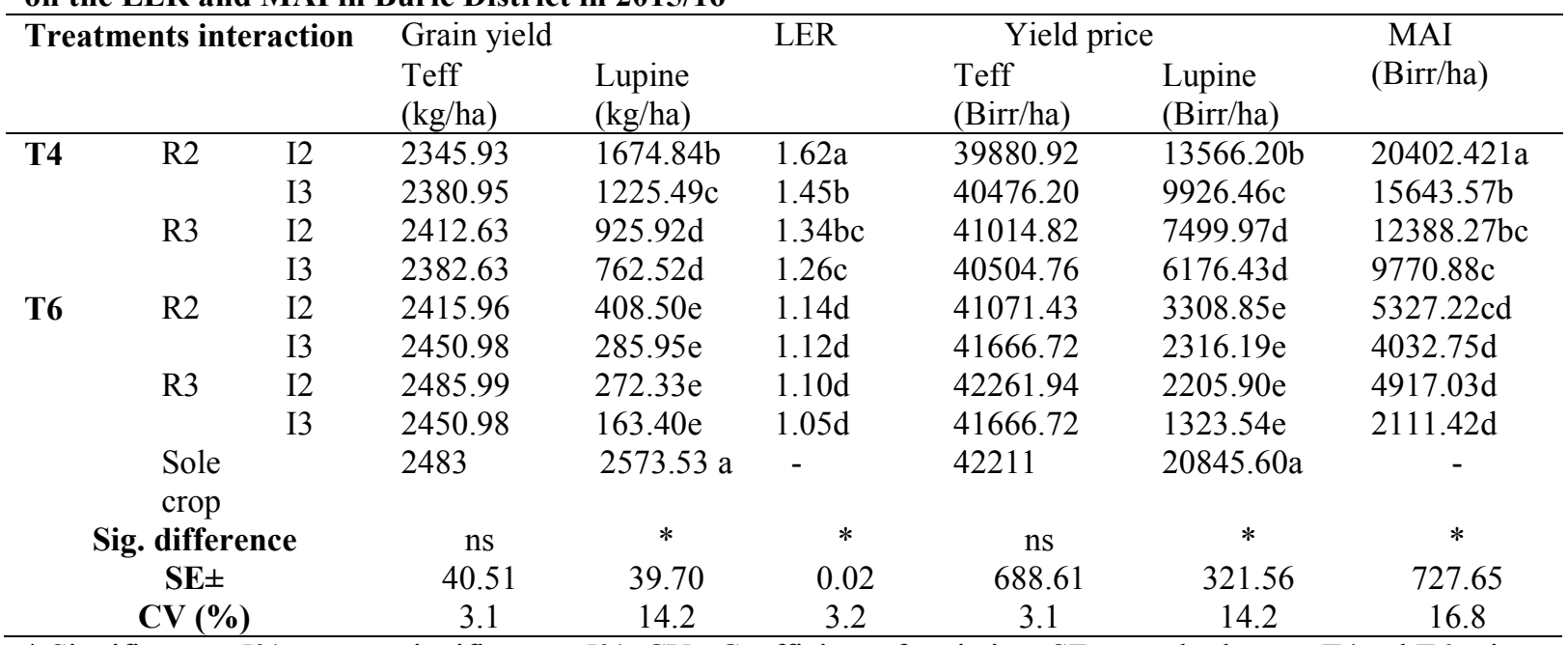

* Significant at $5 \% ; \mathrm{ns}=$ not significant at $5 \% ; \mathrm{CV}=$ Coefficient of variation; $\mathrm{SE}=$ standard error; $\mathrm{T} 4$ and $\mathrm{T} 6=$ time of relay intercropping after $4 / 6$ weeks of teff sowing respectively, R2 and R3=teff lupine ratio in every after $2 / 3$ teff rows respectively, I2 and I $3=$ intra row spacing of lupine $(20 \mathrm{~cm}$ and $30 \mathrm{~cm})$ respectively; means followed with different letters are significant at 0.05 level of error

\section{CONCLUSION AND RECOMMENDATIONS}

The delayed intercropping of lupine in teff stand was observed to result in shorter and less branched lupine plants. The study also showed that yield parameters of lupine crop; number of pod per plant and seeds per pod were adversely affected by the delayed relay intercropping of lupine in already established teff crop. This leads the failure of lupine crop which was sown 8 weeks after teff sowing, to provide yield and yield related attributes. Similarly the delayed relay intercropping resulted reduced biomass and grain yield as compared to sole lupine has been sown simultaneously which could be due to the shading and higher competition effect of the established teff crop. There for the farmers in the stud district has a great opportunity to earn additional income by early (after 4 weeks of teff sowing) and narrower intra row and inter row $(20 \mathrm{~cm}$ by $40 \mathrm{~cm})$ than sole cropping of teff crop and lupine crop alone.

\section{REFERENCE}

Abdul-RahamanIssahaku(2010). Spatial arrangements and time of introducing an intercrop on the productivity of component crops in maize (Zea mays L) - soybean (Glycine maxL.) merrill) intercropping systems. MSc. 
thesis, University of Kwame Nkrumah, Ghana.PP 58.

Adipala, E., Ocaya, C.P. and Osiru, D.S.O.(2002). Effect of time of planting cowpea (Vignaunguiculata(L.) walp.) Relative to maize (Zea mays 1.) on growth and yield of cowpea.TROPICULTURA20 (2): 49-57.

Bhat, R and A.A .Karim (2009). Exploring the nutritional potential of wild and underutilized legumes.Compre. Rev. Food Sci. Food Saf., 8: 305-331

Bismillah, M.K. and Khaliq, A. (2004). Production of soybean (Glycine max L.) as cotton based intercropped.Journal of Research Science 15(1): 79-84.

Carruthers K., PrithivirajB.Fe.Q.,Cloutier D., Martin R.C., Smith D.L. (2000). Intercropping of corn with soybean, lupin and forages: Silage yield and quality. Eur. J. Agron. 12:103-115.

Confalone A., Lizaso J.I., Ruiz-nogueira B., Lopez-cedron F., Sau F. (2010).Growth photosynthesis active radiation use efficiency, and yield components of field-grown ViciafabaL. under different temperature and photoperiod regimes. Field Crops Research 115,140-148.

European Food Safety Authority (2005). Opinion of the Scientific Panel on Dietetic Products, Nutrition and Allergies on a request from the Commission related to the evaluation of lupin for labelling purposes. $J$. European Food Safety Authority 302: 1-11.

Jansen, P.C.M. (2006) Lupines albusL. In: Brink, M. and Belay, G., Eds., PROTA (Plant Resources of Tropical Africa) Wageningen.

Likawent Yeheyis (2012). Potential of Lupins (Lupinus spp. L.) for Human Use and Livestock Feed in Ethiopia. 1st Edn.,Auflage, Koster, Berlin, Germany, ISBN-13: 9783895747892.

Likawent Yeheyis, C. Kijora, Solomon Melaku, AntenehGirma and K.J. Peters (2010). White lupin (Lupinus albus L.), the neglected multipurpose crop: Its production and utilization in the mixed crop-livestock farming system of Ethiopia. Livestock Res. Rural Dev., Vol. 22.

Maluleke, H.M., Ayisi, K.K. and Whitbread, A.M. (2004). Lablab density and planting-date effects on growth and grain yield in maize-lablab intercrops. pp. 99-105.

Muoneke, C.O., Ogwuche,M.A.O. and Kalu, B.A.( 2007). Effect of maize planting density on the performance of maize/soybean intercropping system in a guinea savannahagroecosystem.African Journal of Agricultural Research 2(12): 667-677.

Odendo M., Kalybara R. (2004). Impact of improved bean varieties in western Kenya. The Highlights, CIAT in Africa Series No. 18.

Sharma N.K, Misra O.R, Khushwaha S.S, Pachilanya N.K 2000. Response of sorghum based intercropping system to chemical fertilizers, FYM and crop residues. Res Crops 1:289-291.

Sheoran, P., Sardana, V. Singh, S. and Bharat Bhusan (2010). Bio-economic evaluation of rainfed maize (Zeamays)- based intercropping system with black gram (Vignamungo) under different spatial arrangements. Indian J.agric. Sci. 80(3): 244-247.

TamiruHirpa, 2013. Maize productivity as affected by intercropping date of companion legume crops. Peak Journal of Agricultural Sciences Vol.1 (5), 70-82

Thippeswamy, Alagundagi S.C. (2001). Intercropping of legumes with sweet sorghum for higher green forage production Department of Agronomy University of Agricultural Sciences Dharwad-580-005 India Karnataka J Agric Sci 14:605-609

Thobatsi, T.J. (2009). Growth and yield response of maize (Zea mays L.) and Cowpea (VignaunguiculataL.) in intercropping system. Masters dissertation. University of Pretoria, South Africa. pp 58-67.

Willey, R.W. (1979) Intercropping, Its Importance and Research Needs. Part 1.Competition and yield Advantages. Agronomy and Research Approaches.Field Crop Abstract, 32, 1-10.

Willey, R.W. and Osiru, D.S.O.(1972). Studies on Mixtures of Maize and Beans (Phaseolus vulgaris) with Particular Reference to Plant Population.Journal of Agricultural Science, 79, 517-529.

Yayeh Bitew, Abay Abera, and Dessalegn Woldegiorgis (2014). Competition Indices of Intercropped Lupine ( Local ) and Small Cereals in Additive Series in West Gojam, North Western Ethiopia : 1296-1305. 